\title{
Politics-Administration on the Dynamic Relations of Elected Officials and Bureaucracy in the Recruitment of Local Career Officials
}

\author{
Erwan Agus Purwanto ${ }^{\mathrm{a}}$, Agus Pramusinto ${ }^{\mathrm{b}}$, and Dwiyanto Indiahono ${ }^{\mathrm{c}}$ \\ Universitas Gadjah Mada, Yogyakarta, Indonesia \\ cdwiyanto.indiahono@mail.ugm.ac.id
}

\begin{abstract}
Changes in Indonesian political system have also changed the relations of elected and bureaucratic officials in the recruitment of career officials. The dynamic relations of elected and bureaucratic officials in the recruitment of career officials in New Order Era, and the Reform Era prior to and post The Law of Civil State Apparatus (UU ASN) became interesting to investigate because it can illustrate the dynamics of politics-administration in Indonesia. This study will answer the question: What is the politics-administration in the dynamic relations of elected and bureaucratic officials in the recruitment of career officials at the local level in Indonesia? Research with qualitative research method to answer research question has been done in Tegal City. This study shows that bureaucrats who were in the same side with Mayor during the New Order era emphasizes its recruitment of the officials on the proximity and political benefits to maintain and enlarge the power. The condition of the elected-bureaucratic official relations in the New Order era illustrates political dominance. In the time of Reform Era prior to UU ASN, the relation between elected and bureaucratic officials tended to show what Svara submitted as a complementary condition. In the time of the Reform Era post the UU ASN, when the Mayor has a high degree of political control, and at the same time because of the UU ASN, the degree of bureaucratic independence was also high, occured a conflict between Mayor and bureaucrats. The results of this study modify Svara's (2001) model of politics-administration complementarity.
\end{abstract}

Keywords: Bureaucracy; Democracy; Elected officials; Recruitment; Merit system

\section{Introduction}

The dynamic relation of elected and bureaucratic officials since the New Order era until the Reform Era has also undergone significant changes. In the New Order era, Civil 
Servants automatically became the members of Corps of Government Employees of Republic of Indonesia (KORPRI) and was affiliated closely to Golkar Party. During the New Order era, the dominance of the central government was held by the Ministry of Home Affairs, which included most of the decision-making authority, appointment of bureaucratic functionaries, taxation, resource allocation, auditors and control for local government and also the implementation of development programs (Mahar, 2008: 16).

The efforts to enforce bureaucratic impartiality and to encourage bureaucracy to remain within the merit system become its own spirit after reformation. Firnas stated that bureaucratic-politics in relation to bureaucratic impartiality in the Reform Era is closely related to positive aspects of behavior such as being accountable, responsive, transparent, corruption-free, neutral, non-discriminatory, polite, and other good values (Firnas, 2016: 187 ). Merit system or competitive selection is also becomes the choice of Mill in terms of recruitment which lies between bureaucratic relation and democracy (van Warden, 2015).

15 years post-Reform Era, Law Number 5 about the State Civil Apparatus 2014, also known as Undang-Undang Nomor 5 tahun 2014 tentang Aparatur Sipil Negara (UU ASN) trying to accommodate the spirit to create a merit system and preventing excessive political intervention on the bureaucracy. The efforts to reform the recruitment policy of bureaucracy as an implementation of regional autonomy in Regional Government Offices are really important because many bureaucrats still want to occupy the elite and prestigious position with the continuous rewards (Budiyanto, 2003: 86).

Recruitment is the process of attracting individuals at the right time, in sufficient quantities, and with appropriate qualifications to fill jobs within an organization (Gooden and Wooldridge, 2007: 68). Recruitment is the process of developing a set of qualified applicants who are interested in working for the organization, and from that group of people the organization can choose the best individuals to fill a job (DeNisi and Griffin, 2001). Recruitment is also specifically defined as a set of activities and processes used legally to obtain the right number of people, at the right place and time, so that people and organizations can choose one person (rather than others) for shortterm and long-term goals of the organization Schuler and Huber, 1997). Recruitment is an important process for an organization. Recruitment of career officials conducted by 
public organizations is not only choosing smart people, but also must choose people who have dedication, honesty, pro public and administrative tasks.

The recruitment of career officials in local government is interesting to be analyzed, because: First, Elected Officials must have an obligation to fulfill their campaign promises and in order to do that, the Elected Officials need the people who is capable to embodying their visions and their missions in the bureaucracy; Second, the local Elected Officials have a little possibility to place the political appointees within the local structure, since there is no post for political people to sit in the bureaucracy at the local level; and Third, the bureaucracy itself has already began the effort to put its best people as leaders in merit out of any political intervention.

The relation between elected and bureaucratic officials has been discussed since the beginning of the Study of Public Administration. The political and administrative dichotomy even became the earliest and hottest discussion of Public Administration Science (Willson, 1987; Goodnow, 1900; White, 1926; Taylor; 1912; Willoughby, 1918). This view of the political dichotomy over time has been largely abandoned by Public Administration researchers. Either the dichotomy or integration of politicsadministration in the recruitment of Elected Officials is important because so far there are some disagreements about the relations between elected and bureaucratic officials on the local level in Indonesia. Especially with the implementation of the UU ASN, there will be a concern of new relations of politics-administration dichotomy.

This matter will be more complicated in addition of the New Public Management paradigm which seems to bring bureaucracy into the post-bureaucratic or antibureaucratic realm. Osborne and Gaebler (1992), and Hughes (1994) pushed the bureaucracy toward the release of public managers from political intervention so it can innovate freely. Elected Officials may drive it, but not rowing it. This is something that needs to be proved, because what happens in reality when the post-bureaucratic is implemented is there will be a new form of bureaucracy called post-bureaucracy (Torsteinsen, 2012 and Liff, 2014), which in fact there will be no structure without hierarchy post-bureaucratic or modern Weber (Höpfl, 2006). Post-bureaucratic is more totalitarian and more democratic; it is more totalitarian because it knows no borders, it is more democratic because it is open to any logic from outside (Maravelias, 2003: 562). Post-bureaucratic is actually just an epic which cannot show any success, it is 
unable to adapt to the diversity and complexity of change in contemporary organization (McSweeney, 2006: 22).

The research on the relations of elected and bureaucratic officials in the recruitment of career officials is done in Tegal City for several reasons: first, Tegal City bureaucracy has conducted a massive demonstration to renounce the leadership of their Mayor (City Mayor), which is considered to have done unprofessional things in the recruitment of the officials; second, the Mayor's response which directly demoted the 9th Echelon II officials who involved in the demonstration, was considered repressive to the bureaucracy (Firdaus, 2015); third, the lawsuit of non-job officials against its Mayor through State Administrative Court and then winning is a case that draws bureaucrats attention in Indonesia because the result can be used as jurisprudence in similar cases (Radar Tegal, 2015); and fourth, the Mayor disregard the Court's decision to repositioning the non-job officials causing a wide attention from career officials nationally, State Civil Service Commission and The Ministery of State Apparatus Empowerment and Bureaucracy Reform. Therefore, a research on the relations of elected and bureaucratic officials from the New Order Era, Reform Era prior to and post the UU ASN become very interesting to be done in the city of Tegal. Based on the background stated above, this study becomes important to answer about: What is the politics-administration in the dynamic relations of elected and bureaucratic officials in the recruitment of career officials at the local level in Indonesia?

\section{Research methods}

This research is done using qualitative research method. Data collection techniques were conducted using in-depth interviews, focus group discussions, documentation and observation. Informants in this study were former Mayor and Vice Mayor of Tegal, the current Vice Mayor Tegal, career officials in the New Order era and Reform Era, retired civil servants, community leaders, and members of Regional Representative Council of Tegal. Data analysis has been done rigorously and cautiously with interactive data analysis techniques. 


\section{The relation of elected and bureaucratic officials in the recruitment of career officials in new order era}

Mayor as one of the officials of the New Order era in the recruitment of career officials, emphasis more on the aspects of proximity and political considerations. The meaning of proximity aspect in this matter is the bureaucracy people who have a personal closeness with the current officials will have a better opportunity to be elected as an official. This personal closeness is built more on personal closeness within Golkar as well as in the real life. The aspect of political considerations indicates that the appointment of officials in the New Order era was an attempt to defend and even enlarge the power of Golkar in the bureaucracy as well as in society.

The established relationship between the elected and bureaucratic officials in the New Order era was built in a tense and rigid atmosphere. In New Order era, there were guidelines used as a mechanism to place an employee into a certain position, namely PDLT - Prestasi, Dedikasi, Loyalitas dan Tidak tercela (Good Achievement, Dedication, Loyalty and Impeccable). This PDLT is a companion to the List of Rank Order (Daftar Urut Kepangkatan-DUK). DUK and PDLT are interconnected and used as the basis for recruitment of career officials in New Order era. Despite of that, Mayor is so feared by his subordinates that in the case of official recruitment, although there are Baperjakat's rules, Mayor's decision is absolute and undeniable. Recruitment of career officials in New Order era empirically showed symptoms of semi-merit system. This refers to the phenomenon of existing efforts to value the aspect of Good Achievements, Dedication and being Impeccable in the recruitment of officials, but also still dominantly put forward the aspects of loyalty and political benefits as the key aspect in placing officials into certain position.

During the New Order era, the organizational structure grew between elected and bureaucratic officials; the effect is that it was difficult to distinguish between real bureaucrats and partisan bureaucrats (Thoha, 2000: 82). The recruitment of career officials believed to be the prerogative right of regional leaders and becomes a powerful spell to appease bureaucratic officials who has a friction against each other. The impact is that many of the bureaucratic officials become sycophants and creating reports only to please their superiors. A bureaucratic official who does not want to lose his position will certainly do anything to please his boss. This is what caused the bureaucracy in the 
New Order era to lose its orientation instead of serving the public but more likely to serve the leaders of the region.

Elected and bureaucratic officials who are always in a same side in official recruitment are the main attribute of the New Order's bureaucracy. This format is actually an empirical answer to the irrelevance of the politics-administration dichotomy in public administration. Nevertheless, the integration of politics-administration in the recruitment of career officials in the New Order era was not an ideal format due to the influx of political considerations and loyalty as the main reference rather than a professional judgment. While the politics-administration dichotomy assumes that administrative work begins when politics finishes its task, the pattern of politicsadministration integration also does not occur because the New Order's bureaucracy and politics cannot be distinguished clearly. Bureaucratic officials are also Political Officials in Golkar, and the Mayor is both the political leader and also the bureaucratic leader. This bureaucracy failed to have an "administrative loyalty". The "administrative loyalty" according to Thorbjørnsrud (2015: 179) is that appointing administrative practices and standards should be far more important than the loyalty to serve the political superiors.

\section{The relation of elected and bureaucratic officials in recruitment of career officials in reform era prior to the $\mathrm{UU} \mathrm{ASN}$}

After the Reform Era, bureaucratic impartiality became an important issue. Bureaucracy is strictly prohibited to be a member or an administrator of political party. Politicsadministration thus begins to re-orientate. Elected Officials who during the New Order era were always in synchronized with the bureaucracy in the political stream, postReform Era began to be separated. Elected and bureaucratic officials begin to be defined in different area. Post-Reform Era to 2014 (before the UU ASN) Tegal City was led by two figures; Adi Winarso (1999-2009), and Ikmal Jaya (2009-2014). In Adi Winarso's term in leading Tegal City, the relation of elected and bureaucratic officials changed significantly. The relationship between Mayor Winarso and the bureaucracy in the recruitment of career officials is very well established. Adi Winarso and Ikmal Jaya are very open with bureaucracy in terms of official recruitment, willing to accept 
suggestions and input from bureaucrats during the recruitment of officials. Baperjakat really seated in an important position in the recruitment of officials.

Mayor Adi Winarso and Mayor Ikmal Jaya's relationship with the bureaucracy have an impact on: first, the growth of bureaucratic trust to Elected Officials in terms of employment policy. This indicates that the bureaucratic leader has indeed been determined in a merit and fair system. Second, the good team working condition between elected and bureaucratic officials. This is because Mayor considers bureaucratic officials to be the people who are eligible to take up the positions. This kind of trust fosters the officials' confidence to work more innovative and creative. Mayor places the bureaucracy as a neutral partner in working for the welfare of the people. Such conception of relationships places bureaucracy as stated by Weber's bureaucracy concepts which are neutral, rational, predictable and efficient in managing the state's affairs (Rodriquez and Stupak 1992: 3).

The relation of elected and bureaucratic officials in the Reform Era before the implement of UU ASN in Tegal City shows the integration of politics-administration which has a very different way with New Order era. While the recruitment of career officials in the New Order era emphasis more in political proximity and benefits, in the Reform Era prior to the UU ASN it emphasis more in embodying a merit system based on the subjectivity of Elected Officials and Baperjakat. Bureaucratic impartiality begins to draw the bureaucracy towards the merit system built by the bureaucracy itself through Baperjakat and also still get the blessing and direction of Elected Officials. This semi merit system with a more objective face is the main feature in the relationship between elected and bureaucratic officials in the recruitment of officials.

This condition is similar with three Lorentzen principles to unravel the tension between elected and bureaucratic officials (Lorentzen, 1985: 412-413). When questioning about post-bureaucratic (flexible bureaucracy), Budd (2007: 531) states that the right way is when Elected Officials and bureaucratic managers free the public service from lack of creativity, innovation and accountability with healthy skepticism. This condition is also mentioned by Dunn, and Legge Jr. (2002: 418-219) as a contemporary approach of partnership, which puts Elected Officials and career officials as partners in working together to fulfill the public interest, designing pro-public policies and satisfactory public services. 


\section{The relation of elected and bureaucratic officials in recruitment of career officials in reform era post-UU ASN}

Tegal City's new Mayor (2014) Siti Masitha Soeparno turned out to choose a different path from the provisions set out in the UU ASN. The former relation of Elected Officials and bureaucracy that tend to lead to merit system, in Siti Masitha Soeparno's leadership (post UU ASN) was brought back to politics-administration integration with more power dominant and the recruitment mechanism which is closed and immeasurable. The attempts to turn the bureaucracy with authoritarian colors can be felt a day after the inauguration. A day after the inauguration, this newly appointed Mayor immediately instructed the change of the executive officer of duty of Regional Secretary. The Regional Secretary is the highest position of bureaucracy in the region, and when this is the first post that being replaced instantly, of course it will cause a negative relations between elected and bureaucratic officials. This Mayor who wins the direct election feels to have a full legitimacy to overhauling the bureaucracy. Recruitment of career officials is done in accordance with the will of the new Mayor. Official recruitment is conducted without a procedure that has been a convention of previous Elected Officials.

Job transfers and demotions become the powerful weapons to frighten the bureaucracy. Echelon II officials who were banned (non-job) because of fighting the Mayor's order were not returned to their former positions although they already win in the court. In this context, the Mayor has succeeded in implementing counterstaffs strategy to control the bureaucracy. Counterstaffs are done by replacing strategic positions within the bureaucratic body to ensure there will be cooperation (Sukmajati, 2013: 46-47).

The main feature of the relation between the elected and bureaucratic officials after the UU ASN in the appointment of officials in Tegal City illustrates two kinds of pulls: the pull of politics-administration integration and the pull of the politicsadministration dichotomy. The pull of politics-administration integration is precisely showed by Elected Officials who keep the bureaucracy under their power. The policy of career official recruitment becomes an arena that is entirely in the hands of the Mayor without any regard to the process and bureaucratic mechanisms commonly practiced. 
This is exactly the same as the Public Service Commission's failure to perform merit selection. Failure is due to bureaucratic loyalty to Elected Officials was growing along with the government which was born democratically (Jahan and Shahan, 2008: 315; Huque and Rahman, 2003). Whereas the deployment of officials relying only on political considerations will only be beneficial in the short term, but can damage the bureaucracy in the long term (Monsod, 2017: 1). The results study of Dahlström, et al (2012: 656) in fifty-two countries indicate that the recruitment of bureaucracy using merit system can reduce corruption, and other factors that have no significant impact such as competitive salary, career stability and internal promotion. Zaloznaya (2015) also stated that authoritarianism and bureaucratic corruption are two inseparable things. In addition, a money politics issues becomes a new virus in the bureaucracy of Tegal City. The bureaucracy was split, there was a bureaucracy that still did not want to take advantage of the opportunity to become officials by bribing, but there are also bureaucrats who are tempted to sit in certain positions by bribing.

The second pull is the politics-administration dichotomy; this is demonstrated by the efforts of the non-job officials to fight against their Mayor in the Administrative Court. The Mayor's decision to incur the officials of Echelon II without being able to point out a mistake is an unconstitutional act. The Echelon II officials felt that they were bureaucratic officials that should not be easily shifted by Elected Officials. The UU ASN itself has guaranteed that high-ranking senior officials cannot be moved at least within two years. This transfer of officials is not easy because it must be through the selection of competence for the new positions. These officials try to maintain the concept that the bureaucracy should be separated from political intervention. And this is a form of politics-administration dichotomy.

\section{Politics-administration's dynamics relation of elected and bureaucratic officials in the recruitment of indonesian officials: modifying the complementarity model - svara (2001)}

Svara mentioned that the politics-administration should be running at the same level of complementarity. The complementarity of politics and administration approaches (that Elected Officials and career officials should complement each other) needs a communication and partnership to work together on identifying citizens' needs to shape 
governance (Svara, 2001: 180). Elected Officials has to be critical and be able to representing citizens in an important task to determine the government's goals and direction and to ensure that the government is heading to the right direction. Career officials and staffs should complement the politicians, engaging with professional values and are responsible for serving citizens and promoting public interest (Svara, 1999: 309; Svara, 2006: 133). Svara states that when the level of the administrator independence and the degree of the Elected Officials' control are at a high, there will be a condition of complementarity.

Figure 1. Understanding the Interaction between Politicians and Administrators

\section{Elected officials: degree of control}

\begin{tabular}{|c|c|c|c|}
\hline \multirow{4}{*}{$\begin{array}{l}\text { Administrators: } \\
\text { level of } \\
\text { independence }\end{array}$} & High & & Low \\
\hline & $\begin{array}{c}\text { Political } \\
\text { dominance }\end{array}$ & & \multirow[t]{3}{*}{$\begin{array}{l}\text { Stalemate or } \\
\text { laissez-faire }\end{array}$} \\
\hline & \multicolumn{2}{|c|}{ Complementarity } & \\
\hline & $\begin{array}{c}\text { Politicians respect } \\
\text { administrative } \\
\text { competence and } \\
\text { commitment }^{*}\end{array}$ & $\begin{array}{l}\text { Administrators are } \\
\text { committed to } \\
\text { accountability and } \\
\text { responsiveness* }\end{array}$ & \\
\hline
\end{tabular}

*Reciprocating values that reinforce the position of other set of officials

Source: Svara (2001: 179)

During the New Order era, the bureaucratic officials have the same side with the Mayor, so the political control is at high level and the bureaucratic independence were at a low level causing a political domination in the government. The period post UU ASN when the level of political control is high, and the level of bureaucratic independence is also very high, there is no longer complementary condition, but there is conflict. This conflict occurs because the political control gets too high (using the authority to transferring and demoting the bureaucracy) and it was done to maintain and 
enlarge the power. On the other hand, the bureaucracy has the momentum to elevate its independence in the form of open selection, and to have a protection from UU ASN. Conflict occurs because the political control gets infiltrated by politics intervention while the bureaucratic independence is also getting higher and higher. The bureaucracy feels itself has its own mechanism and must be separated from political intervention. Svara's theory about when the level of political control is high and bureaucratic independence is also high, there will be complementarity is not proven and otherwise the conflict occurred. At a very high level of independence the politics-administration tends to practice the politics-administration dichotomy. In the Reform Era prior to UU ASN the relation of political-bureaucratic in the recruitment of officials, both the politic control and bureaucratic independence were at moderate level, and it creates a complementary conditions.

Table 1. Empirical Conditions of Relation of Elected Officials and Bureaucracies in the New Order era, Reform Era prior to and post- UU ASN

\begin{tabular}{|c|c|c|c|c|c|}
\hline Phase & $\begin{array}{l}\text { Formal } \\
\text { Reference }\end{array}$ & $\begin{array}{l}\text { Empirical } \\
\text { Reference }\end{array}$ & $\begin{array}{c}\text { Character } \\
\text { Relationships }\end{array}$ & $\begin{array}{l}\text { Analysis using } \\
\text { Svara's Model }\end{array}$ & $\begin{array}{l}\text { Modified Svara's } \\
\text { Model for Tegal } \\
\text { City Context }\end{array}$ \\
\hline $\begin{array}{l}\text { New } \\
\text { Order }\end{array}$ & $\begin{array}{l}\text { The List of } \\
\text { Rank Order } \\
\text { (DUK), and } \\
\text { Good } \\
\text { Achievement, } \\
\text { Dedication, } \\
\text { Loyalty and } \\
\text { Impeccable } \\
\text { (PDLT) }\end{array}$ & $\begin{array}{l}\text { Proximity } \\
\text { and } \\
\text { Political } \\
\text { Interest }\end{array}$ & $\begin{array}{l}\text { The } \\
\text { bureaucracy } \\
\text { obeyed the } \\
\text { mayor }\end{array}$ & $\begin{array}{l}\text { Political } \\
\text { Domination }\end{array}$ & $\begin{array}{l}\text { Political } \\
\text { Domination }\end{array}$ \\
\hline $\begin{array}{l}\text { Reform } \\
\text { Era Prior } \\
\text { to UU } \\
\text { ASN }\end{array}$ & $\begin{array}{l}\text { The List of } \\
\text { Rank Order } \\
\text { (DUK), and } \\
\text { Good } \\
\text { Achievement, } \\
\text { Dedication, } \\
\text { Loyalty and } \\
\text { Impeccable } \\
\text { (PDLT) }\end{array}$ & $\begin{array}{l}\text { Semi Merit } \\
\text { System - } \\
\text { close to } \\
\text { ideal }\end{array}$ & $\begin{array}{l}\text { The } \\
\text { bureaucracy } \\
\text { partnered the } \\
\text { mayor }\end{array}$ & Complementarity & Complementarity \\
\hline $\begin{array}{l}\text { Reform } \\
\text { Era Post } \\
\text { UU ASN }\end{array}$ & $\begin{array}{l}\text { The List of } \\
\text { Rank Order } \\
\text { (DUK) and } \\
\text { Open Selection }\end{array}$ & $\begin{array}{l}\text { Political } \\
\text { Interest }\end{array}$ & $\begin{array}{l}\text { The } \\
\text { bureaucracy } \\
\text { against the } \\
\text { mayor }\end{array}$ & & Conflict \\
\hline
\end{tabular}

Source: Processed from Research Data 2018 
Based on existing data of Svara's complementary model above, there should be a modification to be able to explain the phenomenon of politics-administration in the recruitment of career officials in Indonesia. The modification model is:

Figure 2. Modification of Svara's Models - Understanding the Interaction between Politicians and Administrator

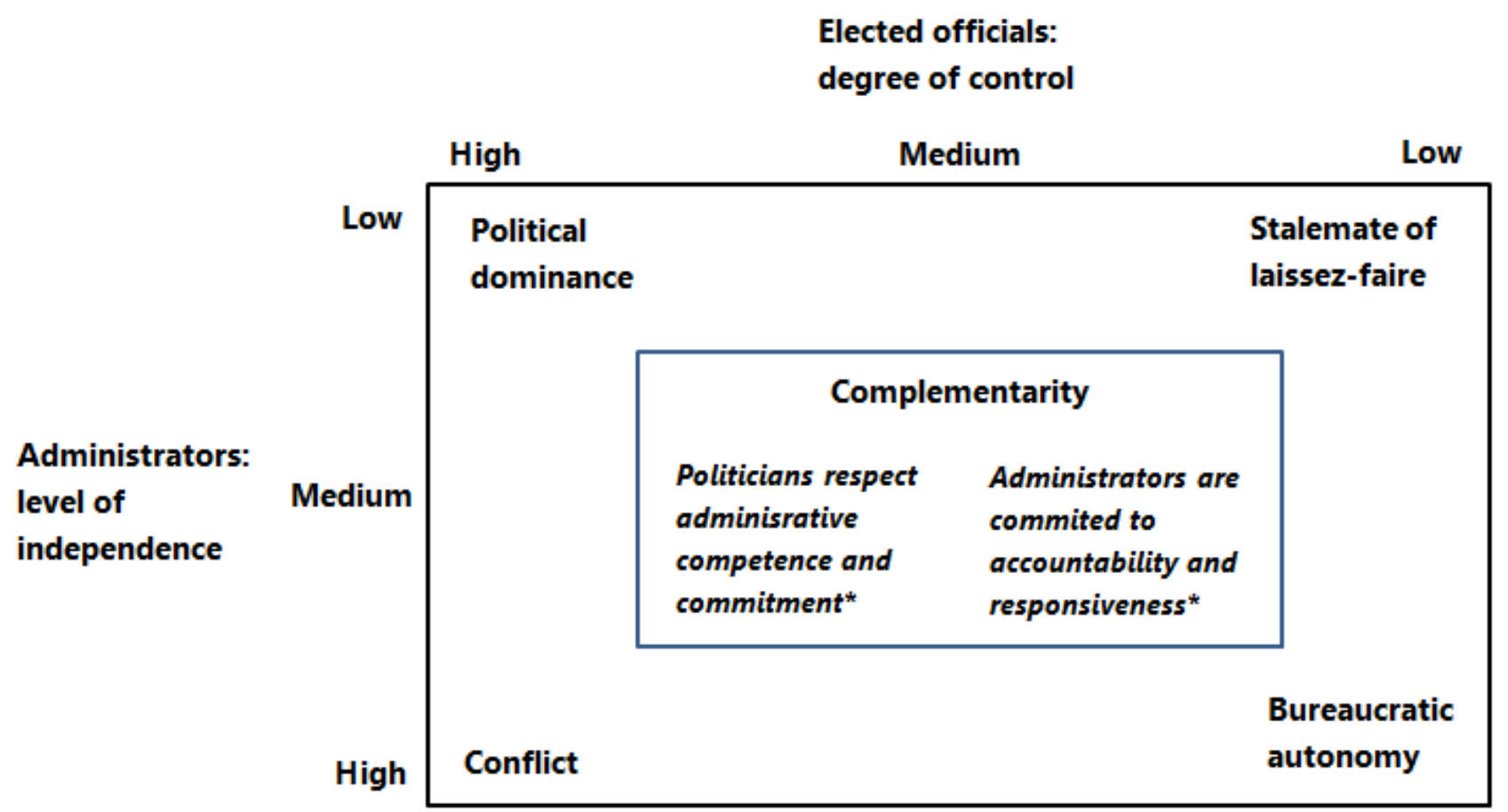

*Reciprocating values that reinforce the position of other set of officials

This model shows that the relationship between Mayor and bureaucracy (politicsadministration) in the recruitment of career officials will be likely lead to five conditions, which are:

First, if the level of political control is high and bureaucratic independence is at low level, then there will be political dominance.

Second, if the level of political control is moderate and bureaucratic independence is also at moderate, then there will be a complementarity condition.

Third, if the level of political control is very high and bureaucratic independence is also very high, conflict will occur. 
Fourth, if the level of political control is low and bureaucratic independence is also low, there will be laissez faire.

Fifth, if the level of political control is low, and the independence of the bureaucracy is at a high level, then a bureaucratic autonomy will be created.

The dynamics of the relation of elected and bureaucratic officials in the New Order era tend to be the first condition, the relation of elected and bureaucratic officials in the Reform Era prior to the UU ASN tend to be the second condition, and the relation of elected and bureaucratic officials in the Reform Era post-the UU ASN tend to be the third condition. To avoid conflicts, and to lower the level of political control, Elected Officials should be aware that career officials are not just subordinates because with the knowledge, abilities, and the experience, they are equal partners. Also to avoid any information gaps between Elected Officials and career officials, Elected Officials need to refrain from politicizing the bureaucracy as well as increasing adequate knowledge of the procedures within the bureaucracy (Ratna, 2012: 38).

\section{Conclusion}

Politics-administration in the officials' recruitment dynamics in New Order era and in the Reform Era before and after the UU ASN provides an interesting picture of the integration and dichotomy of politics-administration. Elected and bureaucratic officials cannot be separated. Both have a strategic role in government. Therefore, the recruitment of career officials is an arena to elect bureaucratic officials who have competence in the required formation, and the bureaucrats elected must have loyalty to the visions and missions of the government. On the other hand, in choosing the officials, the political officers must really pay attention to the competence of the officials needed for the achievement of his political visions and missions. The inclusion of high-level political considerations into the area of recruitment of the career officials has proven to create conflicts within the bureaucracy.

\section{References}

Budd, Leslie. (2007). Post-Bureaucracy Aad Reanimating Public Governance: A Discourse and Practice of Continuity?. International Journal of Public Sector Management, 20(6), 531-547. 
Budiyanto, M. Nur. (2003). Kebijakan Rekrutmen Elit Birokrasi Pemerintah Daerah Kota/ Kabupaten dalam Pelaksanaan Otonomi Daerah. Dinamika Pedesaan dan Kawasan, 3(3), 75-88.

Dahlström, Carl., Lapuente, Victor., and Teorell, Jan. (2012). The Merit of Meritocratization: Politics, Bureaucracy, and the Institutional Deterrents of Corruption. Political Research Quarterly, 65(3), 656-668.

DeNisi, A. S., and R. W. Griffin. (1987). Human Resource Management. Boston: Houghton Mifflin, Co.

Dunn, Delmer D., and Jerome S. Legge Jr. (2002). Politics and Administration in U.S. Local Governments. Journal of Public Administration Research and Theory: $J$ PART, 12(3), 401-422.

Firdaus, Farid. 2015. Ikut Orasi Kritik Mayor Tegal Dirut PDAM Dicopot. Daerah.sindonews.com May 8th 2015 retrieved from https://daerah.sindonews.com/read/999040/22/ikut-orasi-kritik-wali-kota-tegaldirut-pdam-dicopot-1431084971 accessed on July 13th 2017.

Firnas, M. Adian. (2016). Politik Dan Birokrasi: Masalah Netralitas Birokrasi Di Indonesia Era Reformasi. Jurnal Review Politik, 06(01), 160-194.

Gooden, Susan T., and Blue Wooldridge. (2007). Integrating Social Equity into the Core Human Resource Management Course. Journal of Public Affairs Education, 13(1), 59-77.

Goodnow, Frank J. (1900). Politics and Administration: A Study in Government. Newyork: Russel \& Russel. 17-26.

Höpfl, Harro M. (2006). Post-bureaucracy and Weber's "modern" bureaucrat. Journal of Organizational Change Management, 19(1), 8-21.

Hughes, O.E.. (1994). Public Management and Administration: An introduction. London: Macmillan.

Huque, Ahmed Shafiqul., and M. Taiabur Rahman. (2003). From Domination to Alliance: Shifting Strategies and Accumulation of Power by the Bureaucracy in Bangladesh. Public Organization Review, 3(4), 403-418.

Jahan, Ferdous., and Asif Mohammad Shahan. (2008). Politics-Bureaucracy Relationship in Bangladesh: Consequences for the Public Service Commission. Public Organization Review, 8(4), 307-328.

Liff, Roy. (2014). Unintended Consequences of NPM Drive the "Bureaucracy" . International Journal of Public Administration, 37(8), 474-483.

Lorentzen, Paul. (1985). Stress in Political-Career Executive Relations. Public Administration Review, 45(3), 411-414.

Mahar, Ari Indrayono. (2008). Elite dan Birokrasi Pemerintahan di Indonesia. Jurnal Kebijakan dan Administrasi Publik, 2(2), 10-24.

Maravelias, Christian. (2003). Post-Bureaucracy - Control Through Professional Freedom. Journal of Organizational Change Management, 16(5), 547-566.

McSweeney, Brendan. (2006). Are We Living in a Post-Bureaucratic Epoch?", Journal of Organizational Change Management, 19(1), 22-37.

Monsod, Tobi C. (2017). Political appointees in the Philippine bureaucracy: do increasing numbers help or harm?. Philippine Political Science Journal, 38(1), $1-27$. 
Osborne, D., and Gaebler, T.. (1992). Reinventing Government: How the Entrepreneurial Spirit is Transforming the Public Sector. Reading, MA: Addison-Wesley.

Radar Tegal. (2015). Digugat 15 Pegawainya, Wali Kota Tegal Kalah. Radar Tegal December $24^{\text {th }} 2015$ retrieved from https://radartegal.com/berita-lokal/digugat15-pegawainya-wali-kota-tegal-kalah.1382.html accessed on February 19th 2018.

Ratna, Ikhwani. (2012). Reformasi Birokrasi Terhadap Penataan Pola Hubungan Jabatan Politik Dan Karir Dalam Birokrasi di Lingkungan Pemerintah Provinsi Riau. Jurnal Sosial Budaya, 9(1), 14-40.

Rodriquez, C. David., and Ronald J. Stupak. (1992). On The Public Sector : A Dialogue Between Karl Marx And Max Weber. Review of Modern Sociology, 22(1), 1-11.

Schuler, R. S., and V. L. Huber. (1997). Personnel and Human Resource Management. St. Paul, MN: West Publishing Company.

Sukmajati, Mada. (2013). Relasi Birokrat dan Politisi: Penjelajahan Konsep dalam Elisabeth, Adriana; Dede Mariana; dan Awani Irewati (Editor). 2013. Evaluasi Reformasi Birokrasi di Indonesia. AIPI: Jakarta.

Svara, James H. (2006). Complexity In Political-Administrative Relations And The Limits Of The Dichotomy Concept. Administrative Theory \& Praxis, 28 (1),121-139.

Svara, James H. (2001). The Myth of the Dichotomy: Complementarity of Politics and Administration in the Pastand Future of Public Administration. Public Administration Review, 61(2), 176-183.

Svara, James H. (1999). Politics-Administration/Officials-Citizens: Exploring Linkages in Community Governance. Administrative Theory \& Praxis, 21(3), 309-324.

Taylor, Frederick W. (1912). Scientific Management. Except from: Testimony before the US House od Representatives, Januari 25, 1912.

Thoha, Miftah. (2000). Reformasi Birokrasi Publik Pasca New Order: Perubahan tanpa Grand Design. Jurnal Ilmu Sosial dan Ilmu Politik, 4(1), 79-91.

Thorbjørnsrud, Kjersti. (2015). Mediatization of Public Bureaucracies: Administrative versus Political Loyalty. Scandinavian Political Studies, 38(2), 179-197.

Torsteinsen, Harald. (2012). Why Does Post-Bureaucracy Lead to More Formalisation?. Local Government Studies, 38(3), 321-344.

van Waarden, Betto. (2015). John Stuart Mill on Civil Service Recruitment and the Relation between Bureaucracy and Democracy. Canadian Journal of Political Science, 48(3), 625- 645.

White, Leonard D. (1926-renewed 1954). Introduction to The Study of Public Administration. Reprinted by Permission of Prentice Hall, Upper Saddle River: New Jersey.

Willoughby, William F. (1918). The Movement for Budgetary Reform in the States. D. Appleton and Company for the Institute for Government Research: New York. 1918: 1-8.

Wilson, Woodrow. (1987). The Study of Administration. Political Science Quarterly, 2(2), 197-222.

Zaloznaya, Marina. (2015). Does Authoritarianism Breed Corruption? Reconsidering the Relationship Between Authoritarian Governance and Corrupt Exchanges in Bureaucracies. Law \& Social Inquiry, 40(2), 345-376. 